\title{
A Survey on Technologies to Implement Battery Emulators Based on DC/DC Power Converters.
}

\author{
Ruben Hidalgo-León, BSc ${ }^{l}$, Pablo Jácome-Ruiz, BSc ${ }^{2}$, Gonzalo Almeida-Pazmiño, MSc ${ }^{l}$, Javier Urquizo-Guevara, MSc ${ }^{l}$ and \\ Guillermo Soriano-Idrovo, $P h D^{I}$ \\ ${ }^{I}$ Escuela Superior Politécnica del Litoral, ESPOL, Facultad de Ingeniería Mecánica y Ciencias de la Producción, Centro de \\ Energía Renovables y Alternativas, Campus “Gustavo Galindo” Km 30.5 Via Perimetral, P.O. Box 09-01-5863, Guayaquil, \\ Ecuador, rhidalgo@espol.edu.ec,galmeida@espol.edu.ec, jaurquiz@espol.edu.ec,gsorian@espol.edu.ec \\ ${ }^{2}$ Universidad de Chile, Santiago, Chile, psjacome@gmail.com
}

\begin{abstract}
Currently, many researchers from industry and academic institutions are working on the study of electric vehicles, battery systems and renewable energy sources (solar, wind, geothermal, etc.). In order to carry out research on each of these technologies it is required large capital investment for equipment. Additionally, problems must be faced such as variability of environmental parameters, large space requirements, pollution (in some cases), etc. The use of software and hardware to emulate different types of actual batteries shows to be a low-cost and environmentally friendly option due to some of its features. The battery emulator system has the ability to replicate the behavior of any kind of actual battery using a virtual battery model (also known as battery electric model) and a controllable DC/DC power converter to be used in laboratory environments. Moreover, emulators are not only used for batteries, these can be used to emulate fuel cells, photovoltaic systems, wind generators, thermoelectric generator, etc. This survey aims to present the technologies to implement battery emulators based on DC/DC power converters. This survey is split up into five sections. In the first section, as an introduction, we present the advantages offered by the use of battery emulators to the scientific community and the environment. The second section presents a review about batteries (technologies, models, model parameters, etc.) and also it includes the virtual battery models, which are the main components of battery emulators based on DC/DC power converters. In the third section, we present the main $D C / D C$ power converter types used in these systems and their operation modes. Additionally, in section 4 are presented some case studies where different topologies battery emulators based on DC/DC power converters with battery model are analyzed. These topologies are focused on their use in electric vehicles $(E V)$.
\end{abstract}

Keywords—battery emulator; model; parameters; software; hardware; power converter

Digital Object Identifier

(DOI):http://dx.doi.org/10.18687/LACCEI2016.1.1.098

ISBN: 978-0-9822896-9-3

ISSN: 2414-6390

$14^{\text {th }}$ LACCEI International Multi-Conference for Engineering, Education, and Technology: "Engineering Innovations for Global Sustainability", 20-22 July 2016, San José, Costa Rica. 


\title{
A Survey on Technologies to Implement Battery Emulators Based on DC/DC Power Converters.
}

\author{
Ruben Hidalgo-León, BSc ${ }^{1}$, Pablo Jácome-Ruiz, BSc ${ }^{2}$, Gonzalo Almeida-Pazmiño, MSc ${ }^{1}$, Javier Urquizo-Guevara, \\ $\mathrm{MSc}^{1}$ and Guillermo Soriano-Idrovo, $\mathrm{PhD}^{1}$ \\ ${ }^{I}$ Escuela Superior Politécnica del Litoral, ESPOL, Facultad de Ingeniería Mecánica y Ciencias de la Producción, Centro de \\ Energía Renovables y Alternativas, Campus "Gustavo Galindo” Km 30.5 Via Perimetral, P.O. Box 09-01-5863, Guayaquil, \\ Ecuador, rhidalgo@espol.edu.ec, galmeida@espol.edu.ec,jaurquiz@espol.edu.ec, gsorian@espol.edu.ec \\ 2Universidad de Chile, Santiago, Chile,psjacome@gmail.com
}

\begin{abstract}
Currently, many researchers from industry and academic institutions are working on the study of electric vehicles, battery systems and renewable energy sources (solar, wind, geothermal, etc.). In order to carry out research on each of these technologies it is required large capital investment for equipment. Additionally, problems must be faced such as variability of environmental parameters, large space requirements, pollution (in some cases), etc. The use of software and hardware to emulate different types of actual batteries shows to be a low-cost and environmentally friendly option due to some of its features. The battery emulator system has the ability to replicate the behavior of any kind of actual battery using a virtual battery model (also known as battery electric model) and a controllable DC/DC power converter to be used in laboratory environments. Moreover, emulators are not only used for batteries, these can be used to emulate fuel cells, photovoltaic systems, wind generators, thermoelectric generator, etc. This survey aims to present the technologies to implement battery emulators based on DC/DC power converters. This survey is split up into five sections. In the first section, as an introduction, we present the advantages offered by the use of battery emulators to the scientific community and the environment. The second section presents a review about batteries (technologies, models, model parameters, etc.) and also it includes the virtual battery models, which are the main components of battery emulators based on DC/DC power converters. In the third section, we present the main DC/DC power converter types used in these systems and their operation modes. Additionally, in section 4 are presented some case studies where different topologies battery emulators based on DC/DC power converters with battery model are analyzed. These topologies are focused on their use in electric vehicles $(E V)$.
\end{abstract}

Keywords-battery emulator; model; parameters; software; hardware; power converter.

\section{INTRODUCTION}

Currently, the environmental pollution is the major concern of governments around the world because of its harm consequences. The burning of fossil fuels and their derivatives are the main generators of combustion gases. Transportation and power generation are the main sectors that use these fuels [1]. The environmental pollution is the cause of increasing levels of greenhouse gases in the atmosphere [2]. These gases are formed by almost $50 \%$ of carbon dioxide [3]. In recent years, the planet has considerably raised its temperature, this has led to an abnormal weather patterns [4]. The emission of greenhouse gases, as well as the reduction of areas covered

Digital Object Identifier (DOI): http://dx.doi.org/10.18687/LACCEI2016.1.1.098 ISBN: 978-0-9822896-9-3

ISSN: 2414-6390

$14^{\text {th }}$ LACCEI International Multi-Conference for Engineering, Education, and Technology: "Engineering Innovations for Global Sustainability", 20-22 July 2016, San José, Costa Rica. with forests are the main causes of the increase in level of $\mathrm{CO} 2$ in the atmosphere [5].

Every year, either the private or public sectors make efforts to reduce fuel consumption in transportation [6]. EU as an important goal for 2020 intend that $10 \%$ of energy consumption in the transportation proceed from renewable energy sources [7]. These efforts are reflected in an increased use of higher efficiency vehicles, and the use of motors that are powered by electricity rather than fuel [5]. This kind of vehicles are known as electric vehicles $(\mathrm{EV})$ and almost all of manufacturers have released commercial EVs models [8]. The widespread use of EVs will contribute to the reduction of pollution in the environment and in this light, the manufacturers have started offering commercial options [9]. In fact, several countries have been using this type of vehicles, as in the case of Seattle City (USA), which has a fleet of 150 buses covering 14 routes with a distance of 115 miles [10]. In Ecuador, as a government initiative, they are betting on the use of $100 \%$ electric vehicles in public offices [11]. The main benefits of using electric vehicles include reducing the use of fossil fuels, the fuel imports and environmental pollution as well as, the increasing security in the energy sector [10]. The electrification of transportation sector is changing the way how we generate and use energy.

Generally, the energy required by EVs comes from a battery bank included in their fuselage. The EVs efficiency depends mainly on the performance of their battery bank [12]. This efficiency depends on parameters such as: autonomy, acceleration, energy recovery, etc. [13] [14] [15]. Over the years EVs are becoming more efficient and modern (due to mechanical parts are replaced by electric). Generally, the charging process for EVs is done through the power grid. Effects of this process on these electrical networks are subject of analysis in the scientific community [16] [17] [18]. The battery technology and its cost are the major impediment to the massive use of EVs in our society. Now, there are different types of battery technologies available for EVs such as lead acid, NiMH, Li-Ion etc. [19]. Technology of Li-Ion batteries presents advantages regarding other types, such as fast loading, high energy density, durability, high voltage, low weight, low self-discharge, longer life cycle and others [20], however its major disadvantage is its high cost. Li-Ion battery technology 
allow greater savings and efficiencies, but this technology still remain very costly to produce.

Currently, many researchers from industry and academic institutions are studying about electric vehicles, batteries and renewable energy sources (solar, wind, geothermal, etc.), however, the study of these technologies require big capital investments for equipment and trials [21]. There are also problems in variability of environmental parameters, large space requirements, etc. [22]. In the research of batteries, the analysis focuses on areas such as power density, internal resistance, operating temperature, discharge process and life cycle [23]. In order to carry out experiments with batteries for any equipment or $\mathrm{EV}$, researchers draw upon either real batteries or simulation. The most accurate way to perform an experiment is by using real batteries, loads and generators [24]. Real battery can be rechargeable or non-rechargeable [25], being the second type discarded and replaced in each test during experiments. On the other hand, rechargeable batteries also produce problems since the real battery charge capacity varies after each test, due to: the state of charge (SOC), age and temperature [24]. Other problem presented is the assembly and disassembly of the battery in test vehicle. As a result, the use of real batteries for testing may increase the time to release and become expensive and polluting.

Using virtual battery model and controllable DC power converter to replicate the behavior of different battery types is an alternative option of low-cost and environmentally friendly for laboratory settle, even to demonstrate the effectiveness of complete test systems [26]. The battery emulators provide reproducible experimental settings by using programmable converters [27], which can be used for unlimited number of trials. They can also be used to emulate fuel cells, photovoltaic systems, thermoelectric generators [28] [29], etc. The emulators can replicate scenarios in stable or dynamic state by loading characteristic curves of voltage and current (VI) of different battery types [22]. Using weather data (wind, sun, etc.), any battery behavior can be replicated countless times under laboratory conditions without depending on the variability of these resources. Commonly, emulators are formed by a combination of hardware and software. Handling high voltages and currents are required for hardware because the energy used to emulate a source is taken from the power supply [30]. Thus, to conduct research, primarily for the use of renewable energy sources and battery systems are highly convenient the use of emulators.

This survey aims to present the technologies to implement battery emulators based on DC/DC power converters. This survey is split up into five sections. In the first section, as an introduction, we present the advantages offered by the use of battery emulators to the scientific community and the environment. The second section presents a review about batteries (technologies, models, model parameters, etc.) and also it includes the virtual battery models, which are the main components of battery emulators based on DC/DC power converters. In the third section, we present the main DC/DC power converter types used in these systems and their operation modes. Additionally, in section 4 are presented some case studies where different topologies battery emulators based on DC/DC power converters with battery model are analyzed. These topologies are focused on their use in electric vehicles (EV).

\section{BATTERIES}

The batteries allow to supply electric power to any device or flexible electronic systems [31], electric vehicles and power distribution network [32] [33]. Additionally, it is able to store energy from any generating source (conventional and renewable) [34]. In [35] a battery is defined as an electrochemical generator that transforms chemical energy into electricity through oxidation reactions - reduction. It is made up of cells, which are connected in series and parallel to obtain desired voltages and currents [36] [37]. Energy is stored at those cells [38]. The battery life depends on the rate of energy consumption [38] so it is important to investigate the behavior of battery at different discharge rates. Similarly, the accuracy of estimating the state of charge (SOC) in battery is one of the biggest challenges for researchers [39] [40], to maximize the battery use efficiency and prevent over discharge and overload [41] [42].

\section{A. Basic theoretical concepts in the electrical behavior of} batteries.

In the analysis of a battery is important to have clear the basic theoretical concepts for an understanding of its electrical behavior. These concepts are found in all the papers related to battery emulators. Some of these concepts can be summarized as follows:

- Internal resistance: In the virtual battery models, to be discussed later, the internal resistance is a parameter representing the voltage drop caused by current variation in battery [43].

- State of charge (SOC): Amount of energy that can be taken from the battery in relation to the maximum load that can be stored in the battery [44].

- Depth of discharge (DoD): It measures the fraction of permanent load used, since the average discharge current [45].

- Open circuit voltage: it is the battery voltage without load, when it is fully charged [43].

- Battery capacity: it is measured in amp-hours and represents the amount of energy stored [46].

- Rate of charge / discharge: Velocity of the charge process or delivers its power (discharge current) [46].

- Transient Response: Change of battery voltage caused by an alteration in its load current. The transient response can be characterized by RC networks (resistance - capacitance) [47].

$14^{\text {th }}$ LACCEI International Multi-Conference for Engineering, Education, and Technology: "Engineering Innovations for Global Sustainability”, 20-22 July 2016, San José, Costa Rica. 
- Lifecycle: Number of times the battery can be charged / discharged [48].

\section{B. Battery types.}

Nowadays, there are a variety of battery types available on market. The four most commonly models used include NickelMetal Hybrid Lithium-ion, Lead Acid and Lithium Polymer [49]. In Table I can be seen the basic technical parameters of these battery types [50].

TABLE I

TYPES OF BATTERIES

\begin{tabular}{|c|c|c|c|c|}
\hline Battery Type & $\begin{array}{c}\text { Lead } \\
\text { acid }\end{array}$ & Ni-Cd & Ni-MH & $\begin{array}{c}\text { Lithium- } \\
\text { ion }\end{array}$ \\
\hline $\begin{array}{c}\text { Energy density } \\
\text { (W/Kg) }\end{array}$ & $30-50$ & $45-80$ & $60-120$ & $110-160$ \\
\hline Power density & 180 & 150 & $250-1000$ & 1800 \\
\hline $\begin{array}{c}\text { Nominal } \\
\text { voltage }\end{array}$ & $2 \mathrm{~V}$ & $1.25 \mathrm{~V}$ & $1.25 \mathrm{~V}$ & $3.6 \mathrm{~V}$ \\
\hline $\begin{array}{c}\text { Overcharge } \\
\text { tolerance }\end{array}$ & High & Moderate & Low & Very low \\
\hline \begin{tabular}{c} 
Self-discharge \\
\hline $\begin{array}{c}\text { Operating } \\
\text { temperature }\end{array}$
\end{tabular} & $-20-60^{\circ} \mathrm{C}$ & $-40-60^{\circ} \mathrm{C}$ & $-20-60^{\circ} \mathrm{C}$ & $-20-60^{\circ} \mathrm{C}$ \\
\hline Cycle life $^{\mathrm{c}}$ & $200-300$ & 1500 & $300-500$ & $500-1000$ \\
\hline
\end{tabular}

a: Chargeable electric energy per weight of battery pack.

b: Proportion of dischargeable electric energy to charged energy.

c: The number of charging/discharging cycles in battery's entire life

Although all batteries handle the same range of operating temperatures, the Li-Ion batteries are those with better benefits than the rest. Among the main advantages are: higher average nominal output voltage, high energy density and power, low energy loss by self-discharge, no memory effect and longer service life [50] [51] [52]. This battery is used in a variety of applications such as power tools, medical equipment, EVs, satellites, etc. Due to its high energy density and storage efficiency (around 90\%), the Li-Ion batteries are ideal for use in EVs [12].

In Table II, different types of Li-ion batteries [46] are summarized. Currently, researchers have focused their studies in Lithium iron phosphate (LFP - LiFePO4) as the main chemistry composition for batteries [51] [53] [54] [55]. A great advantage of these batteries is the operating temperature range (ranging from -20 to $+60^{\circ} \mathrm{C}$ ) and its high power density.
TABLE II

TYPES OF LI-ION BATTERIES

\begin{tabular}{|c|c|c|c|c|c|c|}
\hline & $\begin{array}{l}\text { Lithium } \\
\text { Iron } \\
\text { Phosphate }\end{array}$ & $\begin{array}{c}\text { Lithium } \\
\text { Manganese } \\
\text { Oxide }\end{array}$ & $\begin{array}{l}\text { Lithium } \\
\text { Titanate }\end{array}$ & $\begin{array}{l}\text { Lithium } \\
\text { Cobalt } \\
\text { Oxide }\end{array}$ & $\begin{array}{c}\text { Lithium } \\
\text { Nickel } \\
\text { Cobalt } \\
\text { Aluminum } \\
\end{array}$ & $\begin{array}{c}\text { Lithium } \\
\text { Nickel } \\
\text { Manganese } \\
\text { Cobalt } \\
\end{array}$ \\
\hline $\begin{array}{c}\text { Cathode } \\
\text { chemistry } \\
\text { descriptor } \\
\end{array}$ & LFP & LMO & LTO & LCO & $\mathrm{NCA}$ & NMC \\
\hline $\begin{array}{c}\text { Specific energy } \\
(\mathrm{Wh} / \mathrm{Kg})\end{array}$ & $80-130$ & $105-120$ & 70 & $120-150$ & $80-220$ & $140-180$ \\
\hline $\begin{array}{c}\text { Energy density } \\
(\mathrm{Wh} / \mathrm{L})\end{array}$ & $220-250$ & $250-265$ & 130 & $250-450$ & $210-600$ & 325 \\
\hline $\begin{array}{c}\text { Specific power } \\
(\mathrm{W} / \mathrm{Kg})\end{array}$ & $1400-2400$ & 1000 & 750 & 600 & $1500-1900$ & $500-3000$ \\
\hline $\begin{array}{c}\text { Power density } \\
\text { (W/L) }\end{array}$ & 4500 & 2000 & 1400 & $\begin{array}{l}1200- \\
3000 \\
\end{array}$ & $4000-5000$ & 6500 \\
\hline $\begin{array}{l}\begin{array}{l}\text { Volts (per cell) } \\
\text { (V) }\end{array} \\
\end{array}$ & $3.2-3.3$ & 3.8 & $2.2-2.3$ & $3.6-3.8$ & 3.6 & $3.6-3.7$ \\
\hline $\begin{array}{c}\text { Cycle life } \\
\text { Self-discharge } \\
\text { (\% per month) }\end{array}$ & $\begin{array}{c}1000-2000 \\
<1 \%\end{array}$ & $\begin{array}{l}>500 \\
5 \%\end{array}$ & $\begin{array}{l}>4000 \\
2-10 \% \\
\end{array}$ & $\begin{array}{l}>700 \\
1-5 \% \\
\end{array}$ & $\begin{array}{l}>1000 \\
2-10 \% \\
\end{array}$ & $\begin{array}{c}1000-4000 \\
1 \%\end{array}$ \\
\hline Cost (per kWh) & $\begin{array}{l}\$ 400- \\
\$ 1200\end{array}$ & $\$ 400-\$ 900$ & $\begin{array}{l}\$ 600- \\
\$ 2000 \\
\end{array}$ & $\begin{array}{l}\$ 250- \\
\$ 450 \\
\end{array}$ & $\begin{array}{l}\$ 600- \\
\$ 1000 \\
\end{array}$ & $\$ 500-\$ 900$ \\
\hline $\begin{array}{c}\text { Operating } \\
\text { temperature } \\
\text { range }\left({ }^{\circ} \mathrm{C}\right)\end{array}$ & -20 to +60 & -20 to +60 & -40 to +55 & $\begin{array}{c}-20 \text { to } \\
+60\end{array}$ & -20 to +60 & -20 to +55 \\
\hline
\end{tabular}

\section{Battery models.}

The battery model is the key part of an emulator. The model can be used to vary the parameters of actual batteries (next section) and simulate different scenarios of charge and discharge. In these scenarios, we can obtain VI (Voltagecurrent) characteristic curves corresponding to actual batteries [56]. These results are transferred via software to the emulator, which behaves similar to the actual battery in study. Therefore emulators can behave as an actual battery, additionally the researchers can use them in another test sceneries (i.e. with different charge/discharge rates) [57].

1) Model types: There are different kind of battery models with varying degrees of complexity. According to [47], there are 3 groups of battery models: mathematicians, electrochemical and electrical. Mathematical models are very complex, which can use equations, mathematical methods and stochastic approaches to represent the battery runtime behavior [58], its efficiency and capacity [59] [60]. In another hand, electrochemical models optimize physical aspects of battery design. These models need long time for analysis because they implement complex numerical algorithms and require specific information from batteries (which is difficult to obtain [61]). In [49] it is defined another classification of models: Electrochemical, analytical, stochastic and electric. Analytical and stochastic models are handled on the basis of equations and probability. Electric models use a combination of resistors, capacitors and voltage/current sources to reproduce the behavior of batteries [62]. These models are easy to use for power sector researchers because they can be designed in simulators (Matlab, Plecs, etc.). Battery electric models can be classified into 3 categories: Thevenin based, impedance based and runtime based [63]. In this survey the battery electric models are called virtual battery models.

According to [64], electric models are also classified as ideal model, linear model and Thevenin model (Fig. 1).

$14^{\text {th }}$ LACCEI International Multi-Conference for Engineering, Education, and Technology: "Engineering Innovations for 


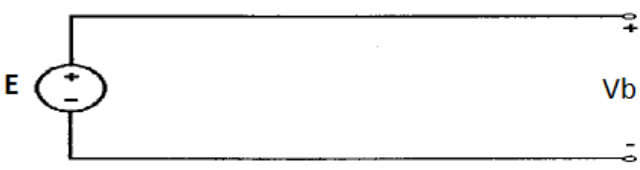

(a)

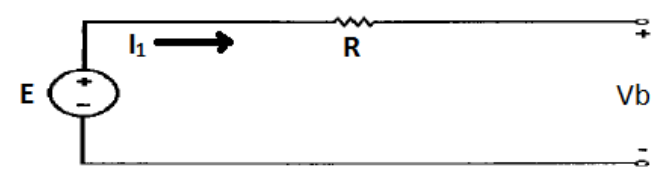

(b)

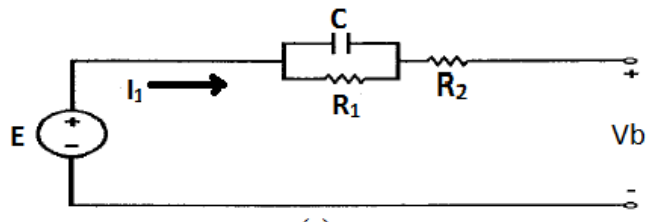

(c)

Fig. 1 Electrical models of batteries, a) Ideal, b) Linear and c) Thevenin, [64].

Fig. 1a) shows the ideal battery model, which consists just of a voltage source. In this model all battery internal parameters are ignored. Fig. 1b) represents a linear model. This model takes into account the internal resistance. The battery voltage $(\mathrm{E})$ and the internal resistance $(\mathrm{R})$ can be represented by expressions (1) and (2).

$$
\begin{aligned}
& E=E_{o}-k \cdot f \\
& R=R_{o}-K_{R} \cdot f
\end{aligned}
$$

Where $E_{o}$ is the battery voltage without load when it is fully loaded; $\mathrm{f}$ is the state of discharge; $R_{o}$ is the internal resistance when the battery is fully charged; $k, K_{R}$ are constants used for experiments. $V_{b}$ is a voltage close to $E$ measured when the circuit current and the capacitor voltage are zero [53].

Fig. 1c) shows a Thevenin electrical model that uses a resistor in series with a parallel RC network. $R_{l}$ represents the contact resistance and $C$ is the behavior of electrodes and electrolyte [65]. This model is used to predict the battery response to load transient events in a particular state of charge (SOC), assuming the open circuit voltage is constant [12] [64]. This model is more accurate compared to the ideal and linear models because it takes into account internal battery parameters. In many publications, the Li-ion batteries are modeled by Thevenin equivalent [66]. As more RC networks are added in series, the complexity increases but greater accuracy for representing battery is achieved [67]. Fig. 2 shows a Thevenin electrical model for a Li-ion battery with 2 network RC [68]. This model also represents the transient response of the battery electrodes.

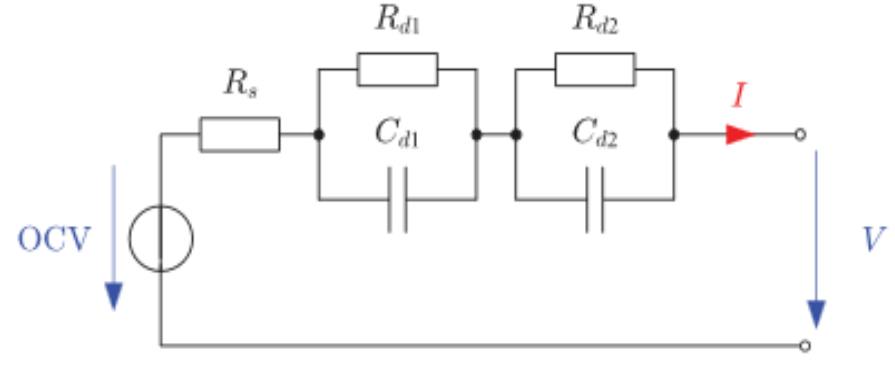

Fig. 2 Thevenin model for Li-Ion battery, [68].

2) Key assumptions in battery models: According to [43], designing battery models requires certain assumptions for analysis and research. Some of them are described as follow:

- Internal resistance is considered constant during the cycles of charge and discharge.

- The load is constant impedance type.

- Internal resistance does not vary with current amplitude.

- Model parameters are obtained from the discharge characteristics and these are assumed equal to the load.

- Battery capacity does not change with the current amplitude.

- Temperature does not affect the model behavior.

- The self-discharge of the battery is not represented.

- Battery has no memory effect.

- Do not take into account the effects of gasification and overload [24].

- Open circuit voltage is constant [12] [64].

\section{Battery model parameters}

The battery model parameters represent the behavior of an actual battery during either charging or discharging processes. In the analysis of a particular battery type is very important to know these parameters. Many times these parameters are deducted from the discharge curve provided by the manufacturer. After getting these parameters, we can build the virtual battery model and replicate the battery behavior inside a simulation platform. A good representation of a battery can implement a Thevenin model together with a Shepherd model. The Shepherd model describes the behavior of the terminal voltage during a change in load current. This type of VI model is discussed in [43] [69] [70] [71]. The combination of models is suitable for a better representation of Li-Ion batteries.

The Shepherd-Thevenin model is shown in Fig. 3, which is governed by the expressions 3, 4 and 5:

14 ${ }^{\text {th }}$ LACCEI International Multi-Conference for Engineering, Education, and Technology: "Engineering Innovations for 


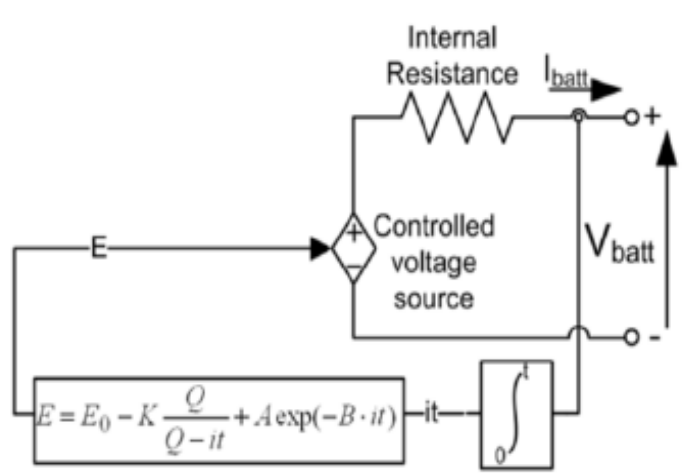

Fig. 3 Shepherd Thevenin battery model, [43].

$$
\begin{array}{r}
\mathrm{SOC}=100 \cdot\left[1-\frac{\left(\int \mathrm{i}\right)}{\mathrm{Q}}\right] \\
\mathrm{V}_{\mathrm{BAT}}=\mathrm{E}-\mathrm{R}_{\text {int }} \cdot \mathrm{I}_{\text {bat }} \\
\mathrm{E}=\mathrm{E}_{\mathrm{o}}-\mathrm{K} \cdot\left(\frac{\mathrm{Q}}{\left(\mathrm{Q}-\int \mathrm{i}\right)}\right)+\mathrm{A} \cdot \mathrm{e}^{(-\mathrm{B} \cdot \mathrm{j} \mathrm{i})}
\end{array}
$$

Where:

- $E_{o}$ represents the open circuit voltage (OCV) of the battery to full capacity.

- $\mathrm{K}$ is the coefficient of polarization resistance $(\Omega)$.

- $\mathrm{Q}$ is the battery capacity (Ah).

- I is the battery current (A).

- $R_{\text {int }}$ is the internal resistance $(\Omega)$.

- A is the amplitude of the exponential region (V).

- $\mathrm{B}$ is the inverse constant of time of exponential area $\left(\mathrm{Ah}^{-1}\right)$.

The nonlinear term $\left(\mathrm{Q} /\left(\mathrm{Q}-\int \mathrm{i}\right)\right)$ represents the variation of the voltage with the current amplitude and the state of battery charge [69]. The expression 5 has been modified to eliminate the phenomenon of algebraic loop and instability [43]. Therefore, this battery model can replicate the actual battery behavior.

As shown in the above expressions, this model does not take into account the temperature influence on battery behavior and it does not characterize the phenomenon of self-discharge [43]. The temperature influence strongly affects on the battery chemistry. The internal resistance can decrease its value when a battery works at high temperatures [72]. Additionally, continuous exposure to high temperatures can lead to reduce service life and increase the rate of self-discharge [72].

Fig. 4 shows a typical discharge curve of an actual battery. In this curve are highlighted the zones where we can get the parameters $A, B, K$ and $E_{o}$, according to the expressions in [43] [71].

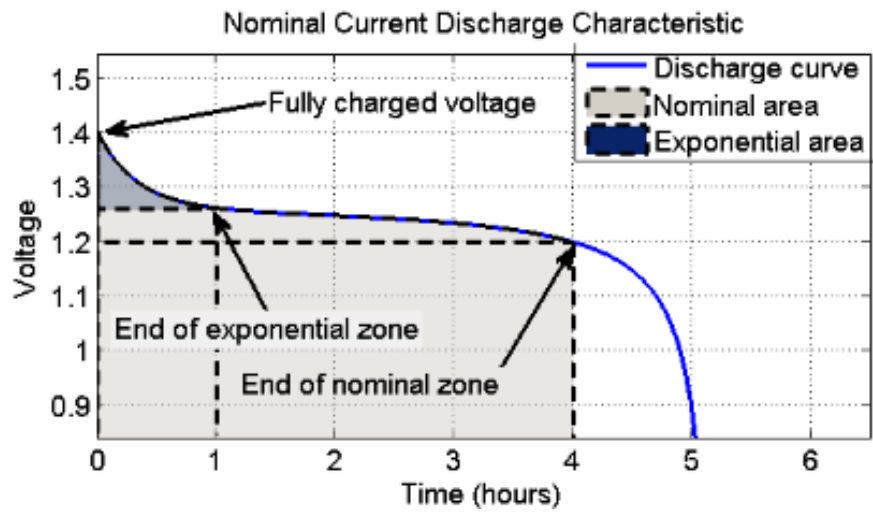

Fig. 4 Typical discharge curve, [43].

$A, B, K$ and $E_{o}$ can be calculated for other battery types, as shown in Table III.

TABLE III

BATTERY PARAMETERS, [43].

\begin{tabular}{|c|c|c|c|c|}
\hline $\begin{array}{c}\text { Type } \\
\text { Parameters }\end{array}$ & $\begin{array}{c}\text { Lead- } \\
\text { Acid } \\
\text { 12V 1.2Ah }\end{array}$ & $\begin{array}{c}\text { Nickel } \\
\text { Cadmium } \\
\mathbf{1 . 2 V ~ 1 . 3 A h}\end{array}$ & $\begin{array}{c}\text { Lithium } \\
\text {-Ion } \\
\text { 3.6V 1Ah }\end{array}$ & $\begin{array}{c}\text { Nickel } \\
\text { Metal-Hydrid } \\
\text { 1.2V 6.5Ah }\end{array}$ \\
\hline $\mathrm{E}_{\mathrm{o}}(\mathrm{V})$ & 12.6463 & 1.2505 & 3.7348 & 1.2848 \\
\hline $\mathrm{R}(\Omega)$ & 0.25 & 0.023 & 0.09 & 0.0046 \\
\hline $\mathrm{K}(\mathrm{V})$ & 0.33 & 0.00852 & 0.00876 & 0.01875 \\
\hline $\mathrm{A}(\mathrm{V})$ & 0.66 & 0.144 & 0.468 & 0.144 \\
\hline $\mathrm{B}(\mathrm{Ah})^{-1}$ & 2884.61 & 5.7692 & 3.5294 & 2.3077 \\
\hline
\end{tabular}

\section{DC/DC POWER CONVERTERS}

Power converters have become highly popular in recent years because of their developed efficiency, flexibility and the capability of connecting various sources of energy at time [73]. The design, modeling and control of converters are fields of extensive research by the scientific community. These devices are able to transfer energy between its ports bi-directionally, enduring positive and negative currents [74]. In addition, they are used as interface between power sources and energy storage systems [75]. One of its main features is the constant output voltage despite variations in their input or load [76]. The DC/DC power converters are connected to the load via a DC-link, as shown in Fig. 5. These characteristics make them suitable for use in EVs.

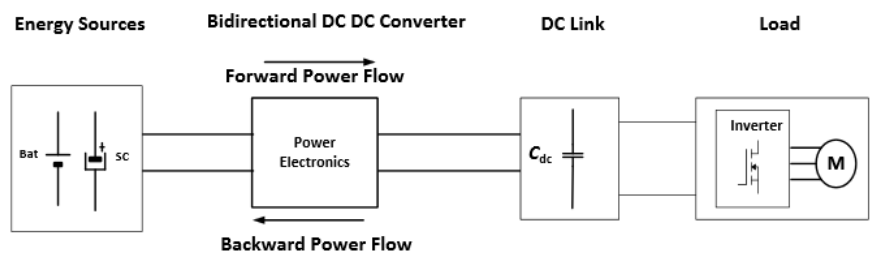

Fig. 5 Diagram of Bidirectional DC/DC converter, [75].

$14^{\text {th }}$ LACCEI International Multi-Conference for Engineering, Education, and Technology: "Engineering Innovations for 


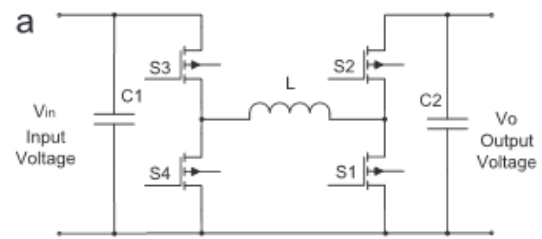

b
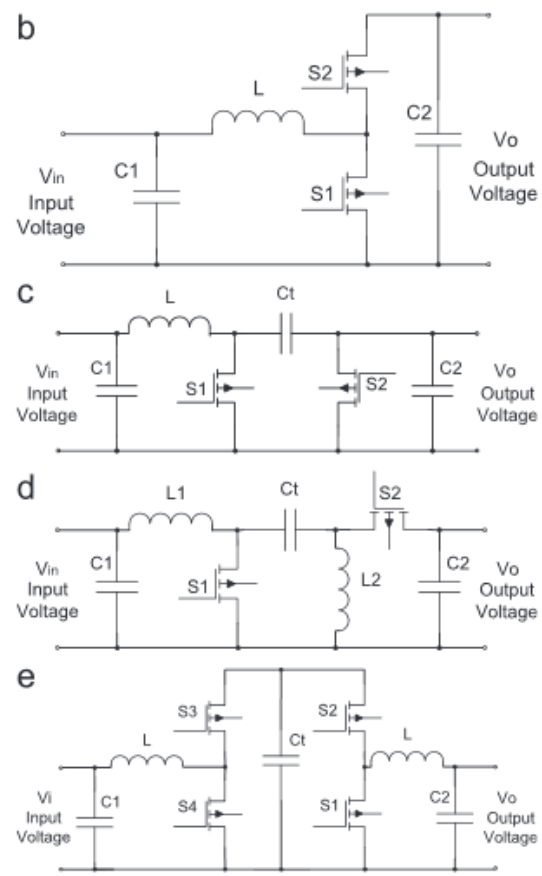

Fig. 6 Bidirectional converters not-isolated a) cascade buck-boost, b) half-bridge, c) cúk, d) sepic y e) split-pi., [79]

Bidirectional converters can be classified into two groups: isolated (galvanic isolation) and not isolated [77]. Distributed generation and storage systems should use isolated converters, when these are connected to the network [78]. Advantage of using galvanic isolation is that it increases the flexibility of the system (meeting required voltage) but also it increase the cost of system. Furthermore, it could be a bit more complicated to design and implement [77]. Not isolated converters are commonly used in battery emulators. Among the most important features we can mention compact size, higher efficiency and use of low voltages. The most used DC/DC power converters in EVs (within the category not isolated) are: buck-boost, half-bridge, cúk, SEPIC and split-pi (Fig. 6) [79]. Despite of the advantages of not insolated converter, some problems can appear, such as pulsating output currents and voltage ripples [76]. In another hand, multiphase converters are formed from buck-boost converter. This survey is focused on buck-boost and multiphase converters.

\section{A. Bidirectional DC/DC power converter: Buck-boost type}

In [80] [81] [82] [83] the operation of buck-boost power converter is shown. This is a bidirectional converter which can have an output voltage either great or less than its input voltage. In Fig. 7, when the converter works in boost mode, the voltage $V_{2}$ (output) is equal to the sum of $V_{1}+V_{L}$ (increasing). In this case $V_{1}$ is the power source. But when this works in the buck mode (reducing), the voltage $\mathrm{V}_{1}$ (output) is equal to $\mathrm{V}_{\mathrm{C}}$ and $\mathrm{V}_{\mathrm{L}}$ (reducer). In this case $\mathrm{V}_{2}$ is the power source.

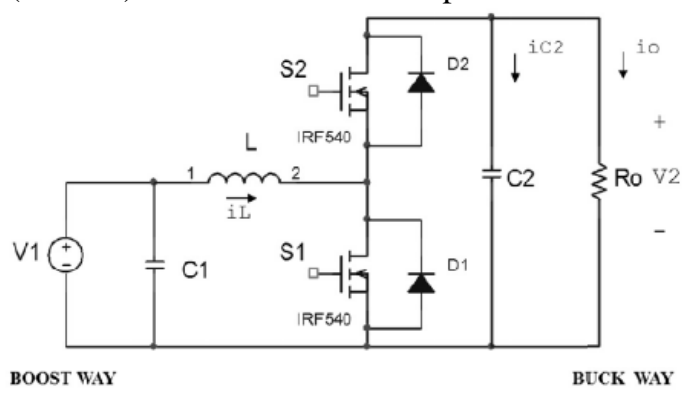

Fig. 7 Buck-boost converter, [74]

$\mathrm{C}_{2}$ (Fig. 7) is the DC-link capacitor when it works in mode of boots. This capacitor can reduce the current ripple to maintain a constant output voltage, and suppress voltage rises caused by switching operations thus providing reactive power [84] [85]. The ideal sizing of this element is crucial because it can become bulky, heavy and expensive [86]. Similarly, the capacitor $\mathrm{C}_{1}$ has the same function and characteristics when the converter is working in buck mode. In another hand, inductors configurations allow store energy and deliver power to the load during switching process [75].

\section{B. Bidirectional DC/DC power converter: Multiphase type}

Multiphase converters are widely used in many applications such as voltage regulator modules, EVs, etc., due to their high efficiency and ability to reduce ripples [87]. In Fig. 8, a multiphase bidirectional voltage converter can be observed ( 8 phases or 8 legs).

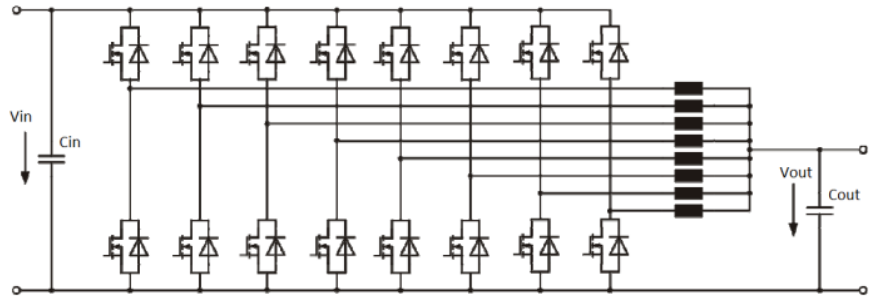

Fig. 8 Bidirectional DC/DC converter: multiphase type, [24].

In the case of buck-boost converter is necessary to increase the switching frequency and to keep low inductance values in order to achieve reduced levels of current ripple, even in small voltage variations between the input and output [24]. Higher switches frequencies can increase energy losses and noise. Thus, to increase the power density, reducing current ripple without increasing the switching frequency, multiphase bidirectional converter are used [88] [89] [90]. These converters are composed of a part that increases the voltage (boost mode) and another that reduces it (buck) [91].

Fig. 9, shows a multiphase converter [92]. As it can be seen in the figure it has three legs. To implement it, firstly the

$14^{\text {th }}$ LACCEI International Multi-Conference for Engineering, Education, and Technology: "Engineering Innovations for 
converter operating mode must be selected (boost or buck). In this configuration, the commutation time for every leg is done sequentially and for this case (Fig. 9) it should be one third of the switching period. The control of switching devices can be performed by PI (Proportional-Integral) controllers [91] or another more advanced control techniques.

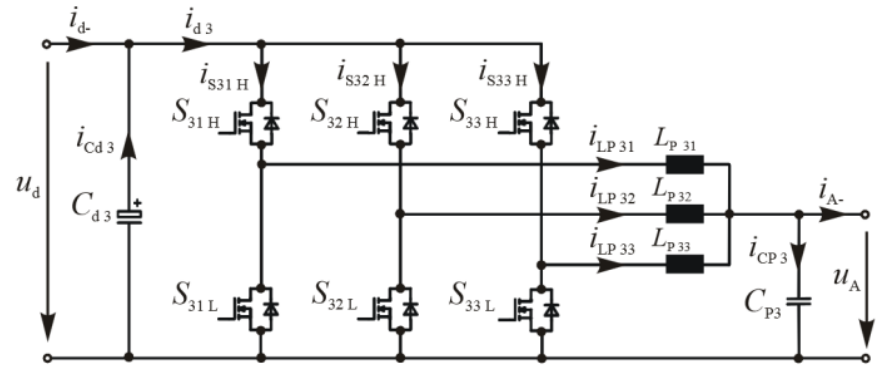

Fig. 9 Multiphase converter, topology 3 legs, [92].

Controlling a larger number of phases can involve the use of specific control schemes. These control techniques should allow synchronization between phases in order to reduce the output voltage ripple and to distribute symmetrically the current between all phases [93] [94].

\section{SOME CASE STUDIES}

In this section, we analyze some of topologies of battery emulators that exist in the literature. Initially we expand a little more the concept of battery emulator. Topologies include virtual battery models and power converters that were discussed in the previous sections.

According to [95] the battery emulators can perform automatic and deterministic testing of EVs propulsion systems within a test bench. These devices can emulate different actual battery types without the need of expensive battery systems. In addition, one of the main advantages is that the state of charge (SOC) and state of health $(\mathrm{SoH})$ can be changed at any time. According to [25] [96], a battery emulator is formed by a controllable power source (controlled by a microcontroller) and a server computer. The emulator is capable to collect power profiles through real-time measurements, and it can save data in a file in the emulator profile mode [27].

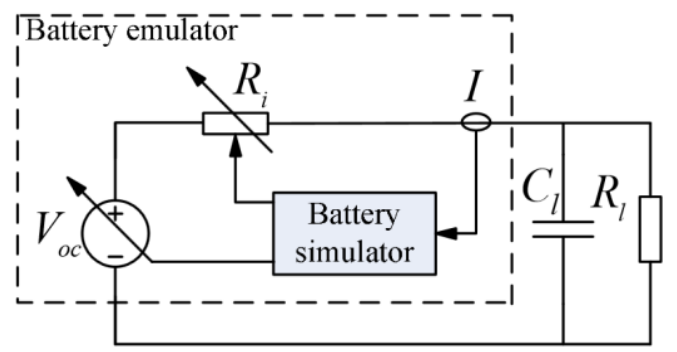

Fig. 10. Circuit model of a battery emulator with load [27].

Fig. 10 shows a battery emulator model circuit [27]. This circuit consists of: a battery linear model, battery simulator, DC-link capacitor and an electrical load. In this study the current and temperature in the battery were measured. Current and temperature measurements determined the set-point of $\mathrm{V}_{\mathrm{OC}}$ and $\mathrm{R}_{\mathrm{i}}$ using DSP (digital signal processor).

In [63], a battery emulator system with a power electronics interface is implemented (Fig. 11). The converter operates with $40 \mathrm{~V}$ input voltage and is tuned to $20 \mathrm{~V}$ output voltage with $6 \mathrm{~A}$ current load.

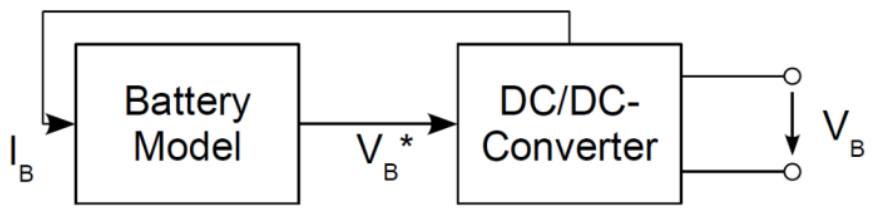

Fig. 11 A circuit model of a battery emulator, [63].

This system consists of an impedance-based battery model. The battery model has as input the emulator current measured $\left(I_{B}\right)$. The battery model, based on $I_{B}$ calculates the battery voltage $V_{B}$, which in turn it is the set point for DC/DC power converter. When the system is in operation, it behaves as an electrochemical storage device which could be integrated into a test bench of electric vehicles or electric traction systems. The power converter is multiphase type (three legs), which can work with voltages and currents up to $400 \mathrm{~V}$ and $400 \mathrm{~A}$, respectively. The multiphase power converter can hold a symmetrical distribution of current load avoiding overloading any leg [93]. In this work, every phase has independent PI control loops. These are part of a decentralized control system. As result, the current is distributed in a symmetrical manner in each leg and the system has a good dynamic behavior according to settings used.

In [24], an emulator with 8 legs multiphase type DC / DC converter is studied. The impedance-based battery model represents a lead-acid battery. This model takes into account the temperature. The control of 8 phases is performed by means of PWM modulation. The modulation frequency is 125 $\mathrm{KHz}$ which is generated by an FPGA (Field Programmable Gate Array) board. The controller is based on PID control. This emulator is used for EV testing. The cranking motor was simulated with various types of batteries and with different temperatures.

In Fig. 12, an emulator for Li-Ion battery is shown [12] with a Thevenin-Shepherd battery model. In the power interface a bidirectional buck-boost type DC/DC converter is employed, which is controlled by a PWM generator. In the converter part, a resistance was placed to emulate the battery charging process, as seen in Fig. 13. In charging process, a diode protects the power supply system. To improve the quality of current and voltage ripple, the capacitors $C_{A}$ and $C_{D}$ were harnessed. An electric vehicle model run as load (similar to [97]). For the battery emulator test, a speed profile was defined. The simulation was performed using Matlab / Simulink. One of the most important outcomes of this experience was the cost reduction for EV trials. 


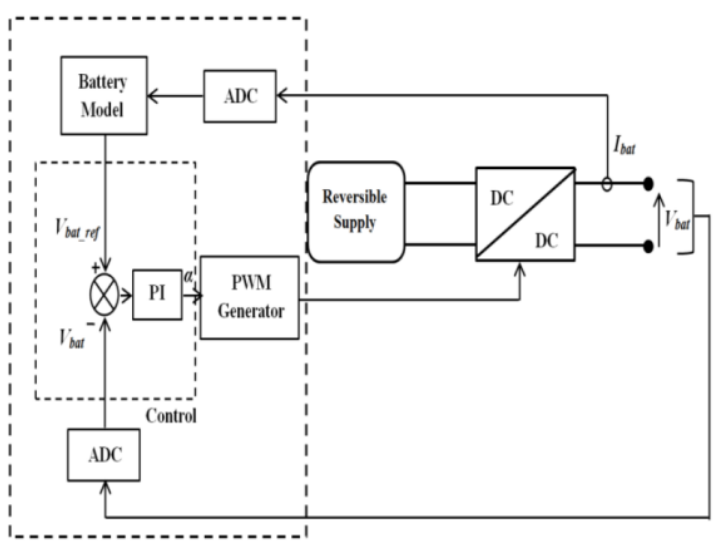

Fig. 12 Battery emulator design, [12].

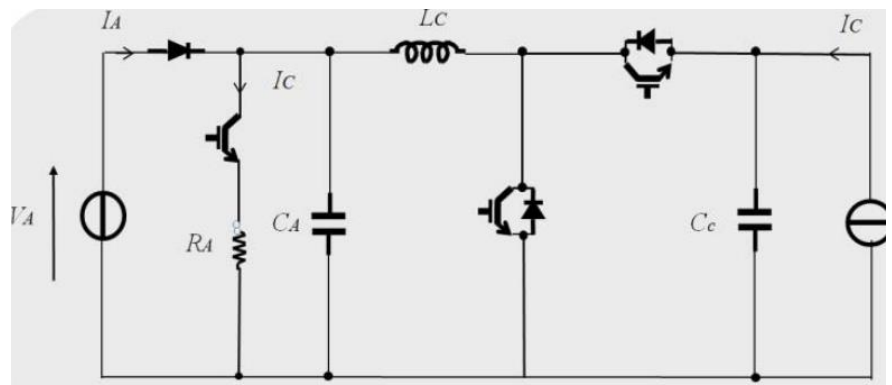

Fig. 13 Buck-boost converter with resistance of charge process, [12].

\section{CONCLUSIONS}

Battery emulators are technological solutions that allow to study of actual battery behavior in EVs and any other types of electric traction systems. Furthermore, it avoids the risks of working with actual batteries.

The use of battery emulators to replicate either the charge or discharge of any actual battery type in a laboratory setting can be a low-cost alternative and environmentally friendly.

Virtual battery model is the main component of battery emulator based on power electronics. The more precise is the virtual battery model, better results are obtained in the emulation process. It is important to note that the general behavior of the actual battery in analysis can be emulated to countless scenarios with different operating conditions.

The more electrochemical variables are taken into account in models, better dynamic performance characteristics of the battery are captured; characteristics such as non-linear open circuit voltage, charge/discharge current, degradation temperature, number of cycles, storage, etc. The addition of RC networks increase the complexity of virtual models but it increase its accuracy.

The battery model parameters represent the behavior of an actual battery during either charging or discharging processes. With these parameters can be built the virtual battery model for replicating the battery behavior inside a simulation platform. Many times these parameters are deducted from the information provided by the manufacturer discharge curve.
The use of multiphase type DC / DC converters in battery emulators involves specific control schemes. These schemes allow the symmetrical distribution of current load between phases in order to reduce the output current ripple.

\section{REFERENCES}

[1] IHS Press, "Oil demand from developed countries has peaked," October 2015. [Online]. Available: http://press.ihs.com/ press-release/energy/oildemand-developed-countries-has-peaked

[2] Australian Government Department of the Environment, "Greenhouse effect," October 2015. [Online]. Available: https://www.environment.gov.au/climate-change

[3] D. Vujatovic and L. Lai, "Reduction in greenhouse gases," in Power Engineering Society General Meeting, 2003, IEEE, vol. 4, July 2003, p. 2023 Vol. 4.

[4] NASA. (2015, October) Global climate change: Vital signs of the planet. [Online]. Available: http://climate.nasa.gov/

[5] DeLucia H., Hamilton G., Naidu L., Thomas R., Andrews A., Finzi A., Schlesinger H., "Net primary production of a forest ecosystem with experimental co2 enrichment," Science, vol. 284, no. 5417, pp. $1177-$ 1179, 1999.

[6] A. Boulanger, A. Chu, S. Maxx, and D. Waltz, "Vehicle electrification: Status and issues," Proceedings of the IEEE, vol. 99, no. 6, pp. 11161138, June 2011.

[7] Damiano, A., Gatto, G., Marongiu, I., Porru, M., \& Serpi, A, "Vehicle to grid technology: state of the art and future scenarios," Journal of Energy and Power Engineering, vol. 8, no. 1, 2014.

[8] Garcia-Valle, Electric vehicle integration into modern power networks. Springer Science \& Business Media, 2012, vol. 2.

[9] A. Boulanger, A. Chu, S. Maxx, and D. Waltz, "Vehicle electrification: Status and issues," Proceedings of the IEEE, vol. 99, no. 6, pp. 11161138 , June 2011.

[10]Department of Ecology State of Washington. (2015, October). [Online]. Available: http://www.ecy.wa.gov/climatechange/ washington electrifytransportation.htm

[11]Agencia Publica de Noticias del Ecuador y Sudamerica - Andes. (2015, October) http://www.andes.info.ec/es/noticias/ecuador-apuesta-usovehiculos-electricos-instituciones-publicas-marco-cambio-matriz.

[12]T. Mesbahi, N. Rizoug, P. Bartholomeus, and P. Le Moigne, "Li-ion battery emulator for electric vehicle applications," in Vehicle Power and Propulsion Conference (VPPC), 2013 IEEE, Oct 2013, pp. 1-8.

[13]P. Mellor, N. Schofield, and D. Howe, "Flywheel and supercapacitor peak power buffer technologies," in Electric, Hybrid and Fuel Cell Vehicles (Ref. No. 2000/050), IEE Seminar, 2000, pp. 8/1-8/5.

[14]Jiang, W., Fahimi, B., "Phase-shift controlled multilevel bidirectional dc/dc converter: A novel solution to battery charge equalization in fuel cell vehicle," in In Vehicle Power and Propulsion Conference, 2007. VPPC 2007. IEEE, 2007, pp. 587-590.

[15]F. Ju, J. Wang, J. Li, G. Xiao, and S. Biller, "Virtual battery: A battery simulation framework for electric vehicles," Automation Science and Engineering, IEEE Transactions on, vol. 10, no. 1, pp. 5-15, Jan 2013.

[16]S. Hadley and A. Tsvetkova, "Potential impacts of plug-in hybrid electric vehicles on regional power generation," pp. 56-68, 2009.

[17]V. Marano and G. Rizzoni, "Energy and economic evaluation of phevs and their interaction with renewable energy sources and the power grid," in Vehicular Electronics and Safety, 2008. ICVES 2008. IEEE International Conference on, Sept 2008, pp. 84-89.

[18]G. Jungmeier, J. Dunn, A. Elgowainy, E. Ozdemir, S. Ehrenberger, H. Althaus, and R. Widmer, "Key issues in life cycle assessment of electric vehicles x2014; findings in the international energy agency (iea) on hybrid and electric vehicles (hev)," in Electric Vehicle Symposium and Exhibition (EVS27), 2013 World, Nov 2013, pp. 1-7.

[19]A. Szumanowski, C. Yuhua, and P. Piorkowski, "Method of battery adjustment for hybrid drive by modeling and simulation," in Vehicle Power and Propulsion, 2005 IEEE Conference, Sept 2005, pp. 7 pp.-.

$14^{\text {th }}$ LACCEI International Multi-Conference for Engineering, Education, and Technology: "Engineering Innovations for 
[20]P.-L. Huynh, O. Abu Mohareb, M. Grimm, H.-C. Reuss, H.-J. Maurer, and A. Richter, "Impact of cell replacement on the state-of-health for parallel li-ion battery pack," in Vehicle Power and Propulsion Conference (VPPC), 2014 IEEE, Oct 2014, pp. 1-6.

[21]R. Shah and A. Rana, "Comparison between voltage controlled and current controlled buck converter based photovoltaic emulator," in Electrical, Electronics, Signals, Communication and Optimization (EESCO), 2015 International Conference on, Jan 2015, pp. 1-5.

[22]S. Thale, R. Wandhare, and V. Agarwal, "A novel low cost portable integrated solar pv, fuel cell and battery emulator with fast tracking algorithm," in Photovoltaic Specialist Conference (PVSC), 2014 IEEE 40th, June 2014, pp. 3138-3143.

[23]A. F. Burke, "Batteries and ultracapacitors for electric, hybrid, and fuel cell vehicles," Proceedings of the IEEE, vol. 95, no. 4, pp. 806-820, April 2007.

[24]T. Baumhofer, W. Waag, and D. Sauer, "Specialized battery emulator for automotive electrical systems," in Vehicle Power and Propulsion Conference (VPPC), 2010 IEEE, Sept 2010, pp. 1-4.

[25]P. Chou, C. Park, J. Park, K. Pham, and J. Liu, "B: a battery emulator and power profiling instrument," in Low Power Electronics and Design, 2003. ISLPED '03. Proceedings of the 2003 International Symposium on, Aug 2003, pp. 288-293.

[26]O. Konig, C. Hametner, G. Prochart, and S. Jakubek, "Battery emulation for power-hil using local model networks and robust impedance control," Industrial Electronics, IEEE Transactions on, vol. 61, no. 2, pp. 943-955, Feb 2014.

[27]K. Nguyen-Duy, A. Knott, and M. Andersen, "A review on the implementation of nonlinear source emulators," in Power and Electrical Engineering of Riga Technical University (RTUCON), 2014 55th International Scientific Conference on, Oct 2014, pp. 56-62.

[28]M. Cernaianu, C. Cirstea, and A. Gontean, "x0106;uk converter employing indirect current control loop for teg energy harvesting devices," in Design and Technology in Electronic Packaging (SIITME), 2012 IEEE 18th International Symposium for, Oct 2012, pp. 193-196.

[29]M. Kesler, E. Ozdemir, M. Kisacikoglu, and L. Tolbert, "Power converter-based three-phase nonlinear load emulator for a hardware testbed system," Power Electronics, IEEE Transactions on, vol. 29, no. 11, pp. 5806-5812, Nov 2014.

[30]T. Cabeza, J. Sanz, M. Calavia, R. Acerete, and S. Cascante, "Fast charging emulation system for electric vehicles," in Electric Vehicle Symposium and Exhibition (EVS27), 2013 World, Nov 2013, pp. 1-6.

[31]J. MacKenzie and C. Ho, "Perspectives on Energy Storage for Flexible Electronic Systems," Proceedings of the IEEE, vol. 103, no. 4, pp. 535553, April 2015.

[32]S. T. Cha, H. Zhao, Q. Wu, A. Saleem, and J. Ostergaard, "Coordinated control scheme of battery energy storage system (bess) and distributed generations (dgs) for electric distribution grid operation," in IECON 2012 - 38th Annual Conference on IEEE Industrial Electronics Society, Oct 2012, pp. 4758-4764.

[33]S. Sirisukprasert, "Power electronics-based energy storages: A key component for smart grid technology," in Electrical Engineering Congress (iEECON), 2014 International, March 2014, pp. 1-7.

[34]D. Budh and V. Virulkar, "Smoothing control for BESS based hybrid renewable energy system," in Electrical, Electronics and Computer Science (SCEECS), 2014 IEEE Students' Conference on, March 2014, pp. $1-4$.

[35]N. Ferry, S. Ducloyer, N. Julien, and D. Jutel, "Fast electrical battery model builder for embedded systems," in Faible Tension Faible Consommation (FTFC), 2011, May 2011, pp. 47-50.

[36]K. Divya and J. Østergaard, "Battery energy storage technology for power systemsan overview," Electric Power Systems Research, vol. 79, no. 4, pp. 511-520, 2009.

[37]A. Subburaj and S. Bayne, "Analysis of dual polarization battery model for grid applications," in Telecommunications Energy Conference (INTELEC), 2014 IEEE 36th International, Sept 2014, pp. 1-7.

[38]M. Jongerden and B. Haverkort, "Battery modeling," Enschede, January 2008. [Online]. Available: http://doc.utwente.nl/64556/
[39]L. Xue, J. Jiuchun, Z. Caiping, Z. Weige, and S. Bingxiang, "Effects analysis of model parameters uncertainties on battery soc estimation using h-infinity observer," in Industrial Electronics (ISIE), 2014 IEEE 23rd International Symposium on, June 2014, pp. 1647-1653.

[40]Y. Jeong, Y. Cho, J. Ahn, S. Ryu, and B. Lee, "Enhanced coulomb counting method with adaptive SOC reset time for estimating OCV," in Energy Conversion Congress and Exposition (ECCE), 2014 IEEE, Sept 2014, pp. 1313-1318.

[41]C. Yin, Q. Zhong, Y. Chen, and S. ming Zhong, "Estimating the state of charge of lithium batteries based on fractional-order sliding-mode observer," in Fractional Differentiation and Its Applications (ICFDA), 2014 International Conference on, June 2014, pp. 1-6.

[42]X. Chen, W. Shen, Z. Cao, and A. Kapoor, "A novel approach for state of charge estimation based on adaptive switching gain sliding mode observer in electric vehicles ," Journal of Power Sources, vol. 246, pp. $667-678,2014$. [Online]. Available:

http://www.sciencedirect.com/science/article/pii/S0378775313013797

[43]O. Tremblay, L. Dessaint, and A. Dekkiche, "A generic battery model for the dynamic simulation of hybrid electric vehicles," in Vehicle Power and Propulsion Conference, 2007. VPPC 2007. IEEE, Sept 2007, pp. 284289.

[44]A. Thanheiser, T. Kohler, C. Bertram, and H. Herzog, "Battery emulation considering thermal behavior," in Vehicle Power and Propulsion Conference (VPPC), 2011 IEEE, Sept 2011, pp. 1-5.

[45]R. A. Jackey, "A simple, effective lead-acid battery modeling process for electrical system component selection," SAE Technical Paper, Tech. Rep., 2007.

[46]J. Warner, The Handbook of Lithium-Ion Battery Pack Design Chemistry, Components, Types and Terminology, ELSEVIER, Ed., 2015.

[47]M. Chen and G. Rincon-Mora, "Accurate electrical battery model capable of predicting runtime and I-V performance," Energy Conversion, IEEE Transactions on, vol. 21, no. 2, pp. 504-511, June 2006.

[48]N. Shidore, J. Kwon, and A. Vyas, "Trade-off between PHEV fuel efficiency and estimated battery cycle life with cost analysis," in Vehicle Power and Propulsion Conference, 2009. VPPC '09. IEEE, Sept 2009, pp. 669-677.

[49]N. Ghossein, J. Salameh, N. Karami, M. El Hassan, and M. Najjar, "Survey on electrical modeling methods applied on different battery types," in Technological Advances in Electrical, Electronics and Computer Engineering (TAEECE), 2015 Third International Conference on, April 2015, pp. 39-44.

[50]X. Chen, W. Shen, T. T. Vo, Z. Cao, and A. Kapoor, "An overview of lithium-ion batteries for electric vehicles," in IPEC, 2012 Conference on Power \& Energy. IEEE, 2012, pp. 230-235.

[51]X. Liu, D. Liu, Y. Zhang, Q. Wang, H. Wang, and F. Zhang, "Least squares support vector machine based lithium battery capacity prediction," in Mechatronics and Control (ICMC), 2014 International Conference on, July 2014, pp. 1148-1152.

[52]H. Fang, H. Ma, H. Fan, H. Shi, and Y. Dong, "Lithium-ion batteries life prediction method basedon degenerative characters and improved particle filter," in Prognostics and Health Management (PHM), 2015 IEEE Conference on, June 2015, pp. 1-10.

[53]Y. Li, B. Zhang, M. Chen, D. Yang, and J. Liu, "Investigation of the internal resistance in lifepo4 cells for battery energy storage system," in Industrial Electronics and Applications (ICIEA), 2014 IEEE 9th Conference on, June 2014, pp. 1596-1600.

[54]A. Marongiu, T. Pavanarit, and D. Sauer, "Influence of current and temperature variation on a lifepo4 battery total capacity," in Electric Vehicle Symposium and Exhibition (EVS27), 2013 World, Nov 2013, pp. $1-11$.

[55]L. Yao, J. Aziz, and N. Ramli, "Detail analysis of rc parallel networkbased model for high capacity lithium ferro phosphates battery," in Power Electronics, Machines and Drives (PEMD 2012), 6th IET International Conference on, March 2012, pp. 1-6.

[56]W. Lee and D. Drury, "Development of a hardware-in-the-loop simulation system for testing cell balancing circuits," Power Electronics, IEEE Transactions on, vol. 28, no. 12, pp. 5949-5959, Dec 2013.

14 ${ }^{\text {th }}$ LACCEI International Multi-Conference for Engineering, Education, and Technology: "Engineering Innovations for Global Sustainability", 20-22 July 2016, San José, Costa Rica. 
[57]A. Collet, J. Crebier, and A. Chureau, "Multi-cell battery emulator for advanced battery management system benchmarking," in Industrial Electronics (ISIE), 2011 IEEE International Symposium on, June 2011, pp. 1093-1099.

[58]T. Imai and H. Yamaguchi, "Dynamic battery charging voltage optimization for the longer battery runtime and lifespan," in Consumer Electronics (GCCE), 2013 IEEE 2nd Global Conference on, Oct 2013, pp. 219-223.

[59]P. Pascoe and A. Anbuky, "VRLA battery discharge reserve time estimation," Power Electronics, IEEE Transactions on, vol. 19, no. 6, pp. $1515-1522$, Nov 2004.

[60]S. Li and B. Ke, "Study of battery modeling using mathematical and circuit oriented approaches," in Power and Energy Society General Meeting, 2011 IEEE, July 2011, pp. 1-8.

[61]D. Dees, V. Battaglia, and A. Belanger, "Electrochemical modeling of lithium polymer batteries," Journal of power sources, vol. 110, no. 2, pp. 310-320, 2002.

[62]S. Abu-Sharkh and D. Doerffel, "Rapid test and non-linear model characterisation of solid-state lithium-ion batteries," Journal of Power Sources, vol. 130, no. 1, pp. 266-274, 2004.

[63]A. Thanheiser, W. Meyer, D. Buecherl, and H. Herzog, "Design and investigation of a modular battery simulator system," in Vehicle Power and Propulsion Conference, 2009. VPPC '09. IEEE, Sept 2009, pp. 15251528.

[64]Y. Kim and H. Ha, "Design of interface circuits with electrical battery models," Industrial Electronics, IEEE Transactions on, vol. 44, no. 1, pp. 81-86, Feb 1997.

[65]B. Schweighofer, K. Raab, and G. Brasseur, "Modeling of high power automotive batteries by the use of an automated test system," Instrumentation and Measurement, IEEE Transactions on, vol. 52, no. 4, pp. 1087-1091, Aug 2003.

[66]K. Bae, S. Choi, J. Kim, C. Won, and Y. Jung, "LifePO4 dynamic battery modeling for battery simulator," in Industrial Technology (ICIT), 2014 IEEE International Conference on, Feb 2014, pp. 354-358.

[67]T. Zahid, G. Xu, W. Li, L. Zhao, and K. Xu, "Performance analysis of particle filter for SOC estimation of lifep04 battery pack for electric vehicles," in Information and Automation (ICIA), 2014 IEEE International Conference on, July 2014, pp. 1061-1065.

[68]M. Einhorn, F. Conte, C. Kral, and J. Fleig, "Comparison, selection, and parameterization of electrical battery models for automotive applications," Power Electronics, IEEE Transactions on, vol. 28, no. 3, pp. 1429-1437, March 2013.

[69]B. Enache, E. Lefter, and C. Stoica, "Comparative study for generic battery models used for electric vehicles," in Advanced Topics in Electrical Engineering (ATEE), 2013 8th International Symposium on, May 2013, pp. 1-6.

[70]S. Li and B. Ke, "Study of battery modeling using mathematical and circuit oriented approaches," in Power and Energy Society General Meeting, 2011 IEEE, July 2011, pp. 1-8.

[71]C. Shepherd, "Design of primary and secondary cells ii. an equation describing battery discharge," Journal of the Electrochemical Society, vol. 112, no. 7, pp. 657-664, 1965.

[72]C. Park, K. Lahiri, and A. Raghunathan, "Battery discharge characteristics of wireless sensor nodes: an experimental analysis," in Sensor and Ad Hoc Communications and Networks, 2005. IEEE SECON 2005. 2005 Second Annual IEEE Communications Society Conference on, Sept 2005, pp. 430-440.

[73]S. Khosrogorji, H. Torkaman, and F. Karimi, "A short review on multiinput dc/dc converters topologies," in Power Electronics, Drives Systems Technologies Conference (PEDSTC), 2015 6th, Feb 2015, pp. 650-654.

[74]A. Restrepo, C. Ramos-Paja, and E. Franco, "Power control of a bidirectional dc bus for fuel cells applications," Revista EIA, no. 18, pp. 159-170, 2012.

[75]M. Beraki, "Improved power electronic converter topology using a variable inductor for electric vehicles," Ph.D. dissertation, Universidad de Oviedo, 2015.
[76]G. Joseph and V. Renjini, "Analysis and comparison of inductor coupled buck-boost converter combining KY converter and SR buck converter," in Circuit, Power and Computing Technologies (ICCPCT), 2014 International Conference on, March 2014, pp. 254-259.

[77]N. Tan, T. Abe, and H. Akagi, "Experimental discussions on operating frequencies of a bidirectional isolated dc-dc converter for a battery energy storage system," in Energy Conversion Congress and Exposition (ECCE), 2013 IEEE, Sept 2013, pp. 2333-2340.

[78] "IEEE application guide for IEEE STD 1547(TM), IEEE standard for interconnecting distributed resources with electric power systems," IEEE Std 1547.2-2008, pp. 1-217, April 2009.

[79]S. Tie and C. Tan, "A review of energy sources and energy management system in electric vehicles," Renewable and Sustainable Energy Reviews, vol. 20, pp. $82-102,2013$. [Online]. Available: http://www.sciencedirect.com/science/article/pii/ S1364032112006910

[80]D. Hart, Electronica de Potencia, Prentice Hall, Ed., vol. 1.

[81]Ned Mohan, Undeland, Robbins, Electronica de Potencia: Convertidores, aplicaciones y diseño, Mc Graw Hill, Ed., 2009, vol. 3.

[82]Muhammad H. Rashid, Electrónica de Potencia: Circuitos, dispositivos y aplicaciones, Prentice Hall, Ed., 2001, vol. 2.

[83]M. Silva, J. Trovao, and P. Pereirinha, "Implementation of a multiple input dc-dc converter for electric vehicle power system," in Energetics (IYCE), Proceedings of the 2011 3rd International Youth Conference on, July 2011 , pp. $1-8$

[84]H. Wen, W. Xiao, X. Wen, and P. Armstrong, "Analysis and evaluation of DC-link capacitors for high-power-density electric vehicle drive systems," Vehicular Technology, IEEE Transactions on, vol. 61, no. 7, pp. 2950-2964, Sept 2012.

[85]J. Lai, H. Kouns, and J. Bond, "A low-inductance dc bus capacitor for high power traction motor drive inverters," in Industry Applications Conference, 2002. 37th IAS Annual Meeting. Conference Record of the, vol. 2, Oct 2002, pp. 955-962 vol.2.

[86]P. Liutanakul, S. Pierfederici, and F. Meibody-Tabar, "Application of SMC with I/O feedback linearization to the control of the cascade controlled-rectifier/inverter-motor drive system with small DC-link capacitor," Power Electronics, IEEE Transactions on, vol. 23, no. 5, pp. 2489-2499, Sept 2008.

[87]Y. Cho, A. Koran, H. Miwa, B. York, and J. Lai, "An active current reconstruction and balancing strategy with dc-link current sensing for a multi-phase coupled-inductor converter," in Energy Conversion Congress and Exposition (ECCE), 2010 IEEE, Sept 2010, pp. 3414-3419.

[88]P. Dahono, S. Riyadi, A. Mudawari, and Y. Haroen, "Output ripple analysis of multiphase dc-dc converters," in Power Electronics and Drive Systems, 1999. PEDS '99. Proceedings of the IEEE 1999 International Conference on, vol. 2, 1999, pp. 626-631 vol.2.

[89]F. Nurman and A. Arofat, "A current compensator for hybrid power plant using bidirectional multiphase DC-DC converter and supercapacitor," in Power Engineering and Renewable Energy (ICPERE), 2012 International Conference on, July 2012, pp. 1-5.

[90]P. Dahono, S. Riyadi, A. Mudawari, and Y. Haroen, "Output ripple analysis of multiphase dc-dc converters," in Power Electronics and Drive Systems, 1999. PEDS '99. Proceedings of the IEEE 1999 International Conference on, vol. 2, 1999, pp. 626-631 vol.2.

[91]A. Kumar and P. Gaur, "Bidirectional dc/dc converter for hybrid electric vehicle," in Advances in Computing, Communications and Informatics (ICACCI, 2014 International Conference on, Sept 2014, pp. 839-843.

[92]F. Renken, "Multiphase DC/DC converters for hybrid electric vehicles," in Power Electronics and Motion Control Conference (EPE/PEMC), 2010 14th International, Sept 2010, pp. T9-98-T9-105.

[93]L. Alvarez, A. Nogueiras, A. Lago, J. Doval, J. Marcos, L. Eguizabal, and C. Martinez-Penalver, "Design, analysis and modeling of an optimized fuzzy control algorithm for synchronous multiphase dc-dc converters in automotive applications," in Power Electronics Specialists Conference, 2006. PESC '06. 37th IEEE, June 2006, pp. 1-6.

[94]S. Utz and J. Pforr, "Current-balancing controller requirements of automotive multi-phase converters with coupled inductors," in Energy

$14^{\text {th }}$ LACCEI International Multi-Conference for Engineering, Education, and Technology: "Engineering Innovations for Global Sustainability”, 20-22 July 2016, San José, Costa Rica. 
Conversion Congress and Exposition (ECCE), 2012 IEEE, Sept 2012, pp. 372-379.

[95]O. Konig, S. Jakubek, and G. Prochart, "Battery impedance emulation for hybrid and electric powertrain testing," in Vehicle Power and Propulsion Conference (VPPC), 2012 IEEE, Oct 2012, pp. 627-632.

[96]C. Park, J. Liu, and P. Chou, "B: a battery emulator and power-profiling instrument," Design Test of Computers, IEEE, vol. 22, no. 2, pp. 150159, March 2005.

[97]Matlab. (2015, October) Hybrid electric vehicle (HEV) power train using battery model. [Online]. Available:

http://www.mathworks.com/matlabcentral/fileexchange/33310-hybrid-

electric-vehicle--hev--power-train-using-battery-model

14 ${ }^{\text {th }}$ LACCEI International Multi-Conference for Engineering, Education, and Technology: "Engineering Innovations for Global Sustainability", 20-22 July 2016, San José, Costa Rica. 